\title{
MANFAAT LIDAH BUAYA SEBAGAI MASKER UNTUK PERAWATAN KULIT TANGAN KERING
}

\author{
Murnalis, Merita Yanita \\ Program Studi Pendidikan Tata Rias dan Kecantikan \\ Jurasan Tata Rias dan kecantikan \\ Fakultas Pariwisata dan Perhotelan Universitas Negeri Padang \\ E-mail: murnalis.mu@yahoo.com
}

Abstract. The purpose of this study was to analyze the effect of the use of Aloe Vera to overcome dry hand with different frequency of use. This research is an experimental study, the method used is quasiexperimental, the number of samples is 9 people each of three people for each group. Control group (X1) without the use of aloe vera, experimental group 1 (X2) with a frequency of $1 x$ three days, and experimental group 2 (X3) with a frequency of $1 \times 7$ days. Data analysis using Analysis of Variance (ANOVA), followed by Duncan test if there are significant differences in the results of analysis of variance. The results showed that 1) There was no change in the level of dry skin moisture in the control group 2) There was a change in the skin moisture level of the experimental treatment group 1 (X2) with the use of Aloe Vera 1 time 3 days, 3) A change in the moisture level of the hand skin dry in the experimental treatment group 2 (X3) with the use of Aloe Vera 1 time 7 days, 4) There were differences in the effect of dry hand care using Aloe Vera with three different treatments and treatment groups with a frequency of 1 time in 3 days had the best results.

Keywords: Aloe vera mask, dry hand skin.

\section{PENDAHULUAN}

Penampilan merupakan sesuatu yang terlihat pada diri seseorang, yang bisa juga menggambarkan bagaimana orang tersebut. Seseorang yang menaruh perhatian pada dirinya akan menjaga penampilan dengan baik agar disenangi banyak orang. Penampilan fisik merupakan salah satu hal yang perlu dijaga. Kepercayaan diri pada seseorang dapat dimiliki untuk menjadikan penampilan seseorang menjadi menarik dimata orang lain. Penilaian terhadap penampilan terkadang dilihat dari bagian luar tubuh seperti pada bagian kulit.

Menurut Hakim, dkk (2005:14) pengertian kulit dan lapisan jaringan kulit adalah: "Kulit sendiri merupakan lapisan luar dari tubuh dan merupakan organ terbesar dari sistem yang menutupi tubuh pada manusia. Kulit memiliki beberapa lapisan ectodermal, otot-otot yang mendasarinya, tulang, ligamen dan organ internal. Kulit sendiri merupakan perisai alami tubuh untuk melindungi organ-organ tubuh dari paparan sinar matahari dan polusi. Kulit mempunyai permukaan paling halus dan merupakan organ tubuh yang sangat peka terhadap kondisi hormon dan rangsangan."

Setiap orang memiliki jenis kulit yang tidak sama. Ada yang memiliki kulit normal, kulit berminyak, kulit kering dan kombinasi. Rostamailis (2005:20) menjelaskan bahwa: "Jenis kulit dapat dikelompokkan atas beberapa jenis dengan ciri-cirinya sebagai berikut: (1) 
jenis kulit normal, dengan ciri-ciri antara lain: tidak berminyak, bisa berubah menjadi kering, segar, kelihatan sehat dan kosmetik mudah menempel dikulit. (2) jenis kulit berminyak, dengan ciri-ciri antara lain: pori-pori besar, kulit terlihat mengkilat, sering ditumbuhi jerawat dan komedo. (3) jenis kulit kering dengan ciri-ciri antara lain: kulit terlihat kusam / tidak cerah, timbul keriput, pori-pori mengecil dan kosmetik agak susah menyatu dengan kulit. (4) jenis kulit kombinasi, ciri-cirinya antara lain : terlihat dua jenis kulit dibagian hidung, dagu dan dahi berminyak dan bagian lainnya kering $(\mathrm{T})$.

Penjelasan diatas dapat disimpulkan bahwa jenis kulit kering merupakan jenis kulit yang bermasalah karena kulit terlihat kusam dan tidak cerah. Kulit kering disebabkan karena kurangnya produksi minyak sebaceous (minyak) yang mengakibatkan cenderung penuaan dini dan rawan kerut. Muliyawan (2013:141) menjelaskan bahwa "kulit kering adalah kulit dengan kadar air yang kurang atau rendah".

Kulit tidak serta merta dapat bertahan selamanya terhadap kondisi iklim dan suhu lingkungan, seperti paparan sinar matahari dengan kandungan sinar ultra violet (UV) yang dapat mengikis kelembaban kulit yang membuat kelenjar minyak lebih aktif sehingga kulit menjadi lebih berminyak, kering, bersisik dan kusam. Santoso (2012:23) mengatakan bahwa: "Kulit kering sering mengganggu dalam berpenampilan, sudah tentu rasa minder atau tidak percaya diri akan selalu datang dan memberikan ketidaknyamanan dalam berpenampilan. Kulit kering disebabkan oleh beberapa hal, seperti: pertambahan usia, sering beraktivitas dalam ruanagan ber-AC, faktor genetik,cuaca, pola hidup yang tidak sehat, sinar
UV serta kekurangan nutrisi untuk kulit yang berfungsi untuk menjagakesehatan kulit."

Sinar matahari bersama dengan udara yang kotor dapat menimbulkan radikal - radikal bebas yang berbahaya untuk kulit. Menurut Darwati (2013:145) radikal bebas adalah: "Agen pengoksidasi kuat yang dapat merusak sistem pertahanan tubuh yang mengakibatkan kerusakan sel dan penuaan dini, radikal bebas berlebih dalam tubuh dapat merusak senyawa lemak yang dapat menghilangkan elastisitas kekencangan kulit sehingga kulit menjadi kering dan kusam"

Berdasarkan penjelasan diatas dapat disimpulkan bahwa kulit kering dapat disebabkan oleh beberapa hal yang tentunya dapat menggangu kesehatan kulit dan memerlukan perawatan. Selanjutnya Darwati (2013:58) juga mempertegas: yang mengatakan bahwa jenis kulit kering juga membutuhkan perawatan ekstra. Rostamailis (2005:16) menjelaskan bahwa: "Perawatan kulit terbagi atas dua jenis yaitu : perawatan tradisional dan perawatan modern. Perawatan secara tradisional maksudnya perawatan yang dilakukan pada zaman nenek moyang secara turun menurun menggunakan bahan alami yang prosesnya dikerjakan secara alami. Sedangkan perawatan modern adalah dengan menggunakan sediaan kosmetik yang berbahan kimia yang sudah dikemas secara modern/teknologi canggih sehingga bentuknya menarik."

Menurut beberapa pendapat para ali tersebut dapat penulis simpulkan kosmetika untuk perawatan kulit terbagi atas dua yaitu perawatan tradisional dan perawatan modern, perawatan tradisional dipandang lebih baik dari pada perawatan modern, karena perawatan 
tradisional tidak memiliki efek samping jika pemakaian terus menerus. Perwatan kulit secara tradisional dapat menggunakan kosmetika berbahan alami yang dilakukan secara manual seperti menggukan masker.

Sesuai penjelasan Widya (2009:49) bahanbahan kosmetik yang umum digunakan untuk kulit kering adalah jenis masker: "Masker adalah bahan kecantikan yang berwujud sediaan gel, pasta dan serbuk yang dioleskan untuk membersihkan, mengencangkan dan melembabkan kulit'.

Acroni (2012:116) menyatakan bahwa penggunaan masker dapat dilakukan seminggu sekali atau 2 kali seminggu. Sedangkah Pipih (2010:16) juga menyatakan bahwa penggunaan masker dapat dilakukan 2 kali dalam seminggu atau 1 kali dalam seminggu. Namun yang terpenting dalam hal ini adalah melihat kondisi dari kulit yang akan di masker baru dilakukan tindakan perlakuan."

Berdasarkan beberapa pendapat di atas, bahan kosmetika yang umum digunakan untuk kulit kering adalah masker, karena masker memiliki bahan-bahan aktif yang cepat diserap oleh kulit sehingga menjadi lebih lembab. Selain itu untuk memaksimalkan hasil masker pada kulit kering dilakukan pengaplikasian dilakukan selama 1 kali dalam 3 hari atau 1 kali dalam 7 hari.

Penggunaan bahan-bahan alami sangat cocok untuk perawatan kulit tubuh seperti penggunaan lidah buaya. Tim Karya Tani (2013:23) menjelaskan bahwa hasil analisis komponen nutrisi lidah buaya dalam 100 gram memiliki beberapa kandungan. Dapat dilihat pada tabel berikut ini:
Tabel 1. Komponen Nutrisi Lidah Buaya dalam 100gr Gel.

\begin{tabular}{|c|c|}
\hline Komponen & Jumlah \\
\hline Karbohidrat & $0.300 \mathrm{gr}$ \\
Kalori & $1.750-2.300 \mathrm{kal}$ \\
Lemak Nabati & $0.050-0.090 \mathrm{gr}$ \\
Protein & $0.010-0.061 \mathrm{gr}$ \\
Vitamin A & $2.000-4.600 \mathrm{IU}$ \\
Vitamin C & $0.500-4.200 \mathrm{mg}$ \\
Thiamin & $0.003-0.004 \mathrm{mg}$ \\
Riboflavin & $0.01-0.04 \mathrm{mg}$ \\
Niacin & $0.038-0.040 \mathrm{mg}$ \\
Kalsium & $9.920-10.920 \mathrm{mg}$ \\
Besi & $0.060-0.320 \mathrm{mg}$ \\
\hline
\end{tabular}

Berdasarkan Tabel 1. dapat dilihat kandungan pada lidah buaya teridiri beberapa komponen seperti vitamin $\mathrm{A}$ dan vitamin $\mathrm{C}$ yang bermanfaat untuk memberikan nutrisi pada kulit kering dan berguna untuk mencegah penuaan dini. Begitu juga dengan Siregar (2011:158), yang menjelaskan manfaat lendir lidah buaya yang mengandung zat lignin yang mampu menahan hilangnya cairan dari permukaan kulit. Hasilnya, kulit tidak cepat kering dan terlihat awet muda. Hasil penelitian Gita (2015:14) juga mengatakan bahwa lidah buaya sangat bermanfaat untuk meningkatkan kelembaban kulit. Penggunaan lidah buaya untuk perawatan kulit pada tubuh membutuhkan cara yang sedemikian rupa agar kandungan dari lidah buaya dapat meresap kedalam kulit tubuh manusia.

Berdasarkan fenomena yang berhasil penulis rangkum diatas, masalah kulit kering disebabkan oleh cuaca yang cenderung panas dan paparan sinar ultra violet (UV) yang mampu mengikis kelembaban kulit, selain itu faktor dari 
radikal bebas juga merusak senyawa dalam kulit sehingga kulit menjadi cepat kering. Perawatan terbaik kulit tubuh yang kering adalah menggunakan masker yang terbuat dari bahan tradisional salah satunya adalah lidah buaya karena banyaknya kandungan yang terdapat dalam lidah buaya untuk merawat dan menutrisi kulit kering pada tubuh seperti beberapa vitamin dan zat lignin.

Berdasarkan observasi penulis kulit yang kering sering dijumpai pada mahasiswi UNP pada rentang umur 19 tahun - 25 tahun yang mengendarai motor yang tidak menutup seluruh bagian tubuh saat berkendara, khususnya pada bagian tangan, sehingga kulit terpapar langsung oleh sinar UV dan polusi yang mampu membuat kulit menjadi kering. Bagian tubuh yang tidak tertutup sangat rentan terhadap paparan sinar matahari, polusi dan radikal-radikal bebas yang membuat kulit tubuh menjadi kering hingga bersisik. Dari sepuluh orang yang penulis observasi tujuh orang diantaranya mengeluhkan kulit kering sangat mengganggu dan membutuhkan perawatan.

\section{KAJIAN TEORI \\ Kulit}

Kulit adalah organ terluar dari tubuh yang melapisi tubuh manusia. Berat kulit diperkirakan $7 \%$ dari berat tubuh total. Pada permukaan luar kulit terdapat pori-pori (rongga) yang menjadi tempat keluarnya keringat.

Secara umum kulit memiliki 2 lapisan yaitu Epidermis (kulit ari) dan Dermis (kulit jangat) serta terdapat suatu lapisan lemak bawah kulit (Hipodermis) hal ini sesuai dengan pendapat Sulastomo (2013:73) menjelaskan bahwa

\section{Fungsi Kulit}

Dwikarya (2003:95) menjelaskan fungsi kulit sebagai berikut: "Fungsi kulit yaitu perlindungan atau proteksi, mengeluarkan zatzat tidak berguna sisa metabolism dari dalam tubuh, mengatur suhu tubuh, menyimpan kelebihan minyak, sebagai indra peraba, tempat pembuatan vitamin $\mathrm{D}$, mencegah terjadinya kehilangan cairan tubuh yang esensial. Untuk itu, selayaknya kulit senantiasa dijaga dan dipelihara kesehatannya. Bukan hanya kulit wajah atau bagian yang terbuka, melainkan kulit diseluruh tubuh harus dijaga, dari semua bagian kulit tubuh, kulit wajah merupakan bagian yang paling sering mendapat perhatian.

\section{Jenis-Jenis Kulit}

Rostamailis (2005:95), menjelaskan jenis kulit terbagi atas: “1). Jenis kulit normal, dengan ciri-ciri sebagai berikut: tidak bernyimak, tidak kering, segar dan tidak berjerawat. 2). Jenis kulit kering, dengan ciri-ciri seperti: terlihat kering, pori-pori halus, kulit muka tipis dan sensitif (perasa) sekali, serta lekas berkerut karena kelenjar minyak kurang aktif bekerja. 3). Jenis kulit berminyak, dengan ciri-ciri sebagai berikut: pori-pori kulit muka besar dan muka berkilat dan sering ditumbuhi jerawat. 4). Jenis kulit kombinasi, dengan ciri-ciri sebagai berikut: sebagian muka berminyak seperti dahi, hidung, dagu, yang sering disebut dengan daerah $\mathrm{T}$, sebagian kering, biasanya dibawah muka dan bagian lainnya dan adanya jerawat."

\section{Kulit Kering}

Menurut Susiana (2012:17), menjelaskan bahwa kulit kering merupakan: "Kulit yang memiliki tingkat kelembaban yang tipis, dimana kelenjar minyak tidak berproduksi dengan normal. Kulit kering dapat diamati dari pori-pori 
kulit yang kecil, tampak bersisik dan kemerahan apabila terpapar matahari langsung. Kulit kering umumnya ditemukan pada bagian tangan dan kaki baik itu untuk kulit yang memang bertipe kering maupun tipe kulit kombinasi."

\section{Kosmetika}

Rostamailis (2005:14) menjelaskan jenis kosmetika yang sering digunakan dalam perawatan kulit sebagai berikut: "Kosmetika pada dasarnya terdiri atas 3 kelompok sesuai bahan dasar pengolahannya yakni: 1) kosmetika tradisional artinya kosmetika yang terbuat dari bahan-bahan yang berasal dari alam dan diolah secara tradisional yang umumnya turun temurun dari nenek moyang. 2) kosmetik semi tradisinal adalah kosmetik yang bahan dasarnya berasal dari alam dan ditambah bahan pengawet, pengolahannya dilakukan secara modern di dalam pabrik, dikemas dengan bentuk yang indah dan menarik. 3) kosmetik modern adalah kosmetik yang diolah melalui teknologi (di dalam pabrik) memakai bahan kimia di kemas dalam bentuk yang indah dan menarik."

\section{Masker}

Widya (2009:48) menjelaskan masker adalah bahan kecantikan yang berwujud sediaan gel, pasta dan serbuk yang dioleskan untuk membersihkan, mengencangkan dan melembabkan kulit. Masker dapat merangsang sirkulasi aliran darah dan memperbaiki kulit melalui percepatan proses regenerasi serta memberi nutrisi pada jaringan kulit.

\section{Lidah Buaya}

Lidah buaya mengandung berbagai vitamin (kecuali vitamin D), mineral, enzim, saponin, gula rantai yang panjang dan 20 jenis asam amino. Lidah buaya mengandung berbagai senyawa biologis aktif, seperti antrakuinon, mannans asetet, polymannans, antioksidan dan berbagai lektin. Manfaat utama lidah buaya bagi kulit adalah menstimulasi pembentukan jaringan epidermis kulit dan membantu proses regenerai sel kulit (Rosita, 2008:68).

\section{Masker Lidah Buaya}

Linda (2016) Penggunaan masker lidah buaya umumnya digunakan pada daerah wajah, namun tidak dipungkiri penggunaan masker lidah buaya ternyata bisa digunakan disemua bagian kulit pada tubuh, seperti tangan, kaki, punggung dan bagian kulit lain.

\section{Penilaian Tingkat Kelembaban Kulit}

Menurut dr.Gloria (2016) Penilaian kembaban kulit tubuh dapat menggunakan alat skin moisture meter, berikut adalah tampilan alat skin moisture meter

\section{Kerangka Konseptual Dan Hipotesis}

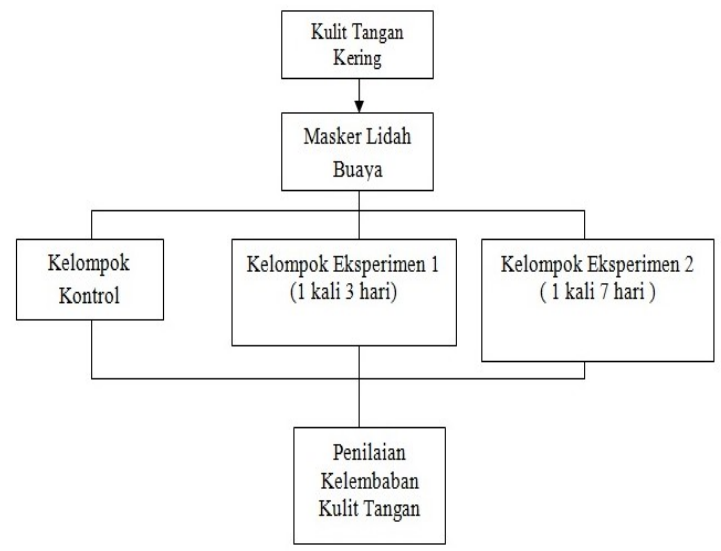

\section{Gambar: Kerangka konseptual}

Hipotesis untuk kerangka konseptual diatas adalah:

Ha: Terdapat perbedaan yang signifikan pada kulit tangan kering tanpa pemanfaatan masker lidah buaya, dengan pemanfaatan masker lidah buaya frekuensi pemakaian 
1 kali 3 hari dan 1 kali 7 hari terhadap kelembaban kulit.

\section{Metode Penelitian}

Penelitian ini termasuk jenis penelitian eksperimen semu (quasi eksperimen). Teknik purposive sampling digunakan dalam pengambilan sampel pada penelitian ini yaitu teknik penentuan sampel dengan pertimbangan tertentu, yaitu mahasiswi UNP berusia 19-25 tahun dengan masalah kulit tangan kering.

Prosedur penelitian dilakukan dengan 3 tahap yaitu tahap persiapan, tahap perlakukan, dan tahap penilaian. Teknik pengumpulan data dengan pengamatan/ observasi, dokumentasi dan perlakuan eksperimen pada sampel.

Teknik analisis data pada penelitian ini menggunakan software SPSS 21. Analisis data menggunakan Analisis Varians (ANOVA), dilanjutkan uji Duncan jika terdapat perbedaan yang signifikan pada hasil analisis varians

\section{HASIL DAN PEMBAHASAN}

\section{Hasil}

\section{Deskripsi Hasil Penelitian pada Kelompok} Kontrol $\left(X_{1}\right)$ tanpa pemanfaatan Lidah Buaya

Penilaian perawatan kulit tangan kering tanpa pemanfaatan Lidah Buaya dapat diuraikan sesuai dengan indikatornya yaitu kelembaban kulit tangan. Skor rata-rata penilaian kelembaban kulit tangan dari tiga orang sampel yang kulit tangan keringnya tanpa menggunakan Lidah Buaya mendapatkan skor 1,00 (sangat kering) pada saat pretest, pertemuan ke 1 skor rata-rata 1,00 (sangat kering), pertemuan ke 2 hingga ke 5 memiliki rata-rata skor 1,33 (sangat kering), pada pertemuan ke 6 memiliki rata-rata
1,67 (kering) dan pada pertemuan ke 7 memiliki skor rata-rata 1,33 (sangat kering).

\section{Deskripsi Hasil Penelitian pada Kelompok} Pemanfaatan Lidah Buaya 1 x 3 hari $\left(X_{2}\right)$

Penilaian perawatan kulit tangan kering menggunakan pemanfaatan Lidah Buaya dengan frekuensi pemakaian 1 kali 3 hari dapat dijelaskan sesuai dengan indikatornya Kelembaban Kulit. Skor rata-rata pada indikator kelembaban kulit dari tiga orang sampel yang kulit tangan keringnya dirawat menggunakan Lidah Buaya dengan frekuensi pemakaian 1 dalam 3 hari menunjukkan skor 1,33 (sangat kering) pada pertemuan ke 1 dan skor rata-rata 1,33 (sangat kering), pertemuan ke 2 skor ratarata 2,33 (kering), pertemuan ke 3 skor rata-rata 2,67 (normal) pertemuan ke 4 skor rata-rata 3,00 (normal), pertemuan ke 5 skor rata-rata 3,67 (lembab), pertemuan ke 6 dan ke 7 skor rata-rata 4,67 (sangat lembab).

Deskripsi Hasil Penelitian pada Kelompok Pemanfaatan Lidah Buaya 1 x dalam 7 Hari $\left(\mathbf{X}_{3}\right)$

Penilaian perawatan kulit tangan keringdengan pemanfaatan Lidah Buaya dengan frekuensi pemakaian 1 kali 7 hari dapat dijelaskan sesuai dengan indikatornya Kelembaban Skor rata-rata pada indikator Kelembab Kulit dari tiga orang sampel yang kulit tangan keringnya dirawat menggunakan Lidah Buaya dengan frekuensi pemakaian $1 \mathrm{x}$ dalam 7 hari mengasilkan skor 1,33 (sangat kering) pada saat pretest, pertemuan ke 1 skor rata-rata 1,33 (sangat kering), pertemuan ke 2 skor rata-rata 1,67 (kering), pertemuan ke 3 skor rata-rata 2,00 (kering), pertemuan ke 4 skor ratarata 2,33 (kering), pertemuan ke 5 skor rata-rata 2,67 (normal), pertemuan ke 6 skor rata-rata 
3,00 (normal), pertemuan ke 7 skor rata-rata 3,67 (lembab).

Berdasarkan analisis Uji Duncan kelompok kontrol $\left(\mathrm{X}_{1}\right)$ dengan rata-rata (1.29) berbeda secara signifikan dengan kelompok perlakuan dengan frekuensi 1 x 7 hari $\left(X_{3}\right)$ dengan nilai rata-rata (2.25), yang tidak berbeda secara signifikan dengan kelompok perlakuan dengan frekuensi 1 x 3 hari $\left(\mathrm{X}_{2}\right)$ dengan skor rata-rata (2.95). Dengan demikian dinyatakan bahwa antara $X_{1}$ berbeda dengan $X_{2}$ dan $X_{3}$, sedangkan $X_{2}$ dan $X_{3}$ tidak berbeda secara signifikan (nyata).

\section{Pengujian Hipotesis}

Hasil uji Hipotesis dilakukan untuk meliahat apakah terdapat perbedaan pengaruh dari tiga perlakuan yang berbeda untuk mengatasi masalah kulit kering dengan indikator kelembaban kulit tangan. Dari hasil uji tersebut ketiga kelompok data berbeda secara signifikan maka dilakukan uji lanjut dengan menggunakan uji Duncan dengn asil kelompok kontrol $\left(\mathrm{X}_{1}\right)$ dengan rata-rata (1.29) berbeda secara signifikan dengan kelompok perlakuan dengan frekuensi 1 $\mathrm{x} 7$ hari $\left(\mathrm{X}_{3}\right)$ dengan nilai rata-rata $(2.25)$, yang tidak berbeda secara signifikan dengan kelompok perlakuan dengan frekuensi 1 x 3 hari $\left(\mathrm{X}_{2}\right)$ dengan skor rata-rata (2.95). Dengan demikian dinyatakan bahwa antara $X_{1}$ berbeda dengan $\mathrm{X}_{2}$ dan $\mathrm{X}_{3}$, sedangkan $\mathrm{X}_{2}$ dan $\mathrm{X}_{3}$ tidak berbeda secara signifikan (nyata).

\section{Pembahasan}

Kondisi kelembaban kulit tangan kering dari ketiga kelompok perlakuan menunjukkan hasil yang berbeda secara rata-rata nilai hal ini dapat diliat dari deksripsi data dan analisis.
Pengukuran yang dilakukan kepada 9 orang sampel dengan tiga perlakuan berbeda dilakukan dengan menggunakan skincheck yang dapat memberikan hasil penilaian sesuai dengan kondisi kulit masing-masing sampel.

Hasil penelitian pada kelompok kontrol $\left(\mathrm{X}_{1}\right)$ yang tidak diberikan perawatan tangan menggunakan lidah buaya menunjukkan skor rata-rata ketiga sampel yang tidak menunjukan hasil pada kondisi kulit normal. Hal ini berarti bahwa tanpa perawatan apapun maka kulit tangan pada sampel tidak akan berubah kondisi menjadi normal dan lembab. Keberhasilan kondisi kulit tangan kering yang terbaik dalam penelitian ini terlihat pada kelompok perlakuan 1 dengan perlakuan pemanfaatan Lidah Buaya dengan frekuensi pemakaian 1 kali dalam 3 hari. Rata-rata hasil pemanfaatan Lidah Buaya pada ketiga sampel telah menunjukkan kondisi normal pada pertemuan ketiga atau setelah tiga kali melakukan perawatan, sedangkan kondisi lembab didapatkan setelah perawatan dengan pemanfaatan lidah buaya pada pertemuan lima atau setelah lima kali mendapatkan pemanfaatan Lidah Buaya. Hal ini berarti bahwa kondisi kulit tangan kering dapat diatasi dengan pemanfaatan Lidah Buaya dengan perawatan yang intensif 1 kali dalam 3 hari dapat memperbaiki kondisi kulit tangan kering menjadi normal dan sangat lembab.

Hasil penelitian untuk pemanfaatan Lidah Buaya dengan frekuensi pemakaian 1 kali dalam 7 hari menunjukkan kondisi kulit tangan kering menjadi normal pada pertemuan ke lima atau pada saat telah lima kali melakukan perawatan dengan pemanfaatan lidah buaya. Kondisi kulit sampel berubah menjadi lembah pada pertemuan ketujuh.Hal ini berati bahwa meskipun kondisi 
kulit tangan kering dapat berubah menjadi lembab namun dalam waktu yang cukup lama yakni 7 minggu.

Hal penelitian ini menunjukkan bahwa pemanfaatan Lidah Buaya untuk mengatasi kondisi kulit tangan kering paling baik adalah dengan pemanfaatan dengan frekuensi pemakaian dalam waktu yang relative singkat yakni 1 kali dalam 3 hari. Sedankgan berdasarkan pengujian statistika ANOVA untuk melibat perbedaan hasil ketiga kelompok perlakuan secara signifikan, diperoleh signifikansi hitung sebesar $0.005<0.050$ yang berarti bahwa Hipotesis yang berbunyi "Terdapat perbedaan pengaruh perawatan tangan kering dengan menggunakan Lidah Buaya dengan tiga perlakuan yang berbeda pada pengujian dengan taraf signifikansi 95\%" diterima. Hal ini secara statsistika bermakna bahwa terdapat satu kelompok yang berbeda, maka dilkukan analisis uji duncan sebagai pengujian lanjut untuk melihat kelompok mana yang berbeda, yang hasilnya menyatakan bahwa antara $\mathrm{X}_{1}$ berbeda dengan $\mathrm{X}_{2}$ dan $\mathrm{X}_{3}$, sedangkan $\mathrm{X}_{2}$ dan $\mathrm{X}_{3}$ tidak berbeda secara signifikan (nyata).

Kulit kering disebabkan oleh kondisi kulit yang kekurangan kelembaban yang yang disebabkan oleh banyak faktor. Menurut Santoso (2012:23) "Kulit kering disebabkan oleh beberapa hal, seperti: pertambahan usia, terlalu sering berada di ruangan yang ber-AC, faktor genetik,cuaca, pola hidup yang tidak sehat, sinar UV serta kekurangan nutrisi untuk kulit yang berfungsi untuk menjagakesehatan kulit."

Kajian teori tersebut berarti bahwa salah satu penyebab adalah kekurangan nutrisi akibat banyak terpapar sinar mata hari, hal inilah yang menyebabkan kulit menjadi kering, karena itu untuk mengatasi kondisi kulit kering tersebut perlu diberikan asupan nutrisi kepada kulit. Salah satu upaya adalah dengan memberikan nutrisi melalu perawatan dengan pemanfaatan bahan-bahan kosmetika tradisional yang diberikan kepada kulit.

Lidah Buaya selama ini telah dipercaya dimasyarakat sebagai komsetika alamiyang memiliki funsi untuk memberikan nutrisi pada kulit, seperti yang dinyakan oleh Furnawanthi (2002:23) bahwa: "Lidah buaya (aloe vera) merupakan tanaman fungsional karena semua bagian dari tanaman dapat dimanfaatkan, baik untuk perawatan tubuh maupun untuk mengobati penyakit, karena lidah buaya mengandung berbagai vitamin (kecuali vitamin D), mineral, enzim, saponin, gula rantai yang panjang dan 20 jenis asam amino. Lidah buaya mengandung berbagai senyawa biologis aktif, seperti antrakuinon,mannans asetet, polymannans, antioksidan dan berbagai lektin.’’

Selain memiliki banyak nutrisi yang berfaedah bagi kulit karena memiliki anti oksidan, Lidah Buaya memiliki fungsi utama untuk menstimulasi pembentukan jaringan epidermis kulit dan membantu proses regenerai sel kulit (Rosita,2008:68). Hal ini berarti bahwa jaringan kulit yang mati diatas permukaan epidermis dapat diatasi dengan memberikan nutrisi kulit untuk proses regenerasi kulit.

Telah diketahui dalam kajian teori tersebut di atas bahwa pemanfaatan Lidah buaya sebagai bahan pelembab kulit dan mengatasi kulit permasalahan kulit kering, dan dari hasil penelitian ini diperoleh pernyataan bahwa pemanfaatan lidah buaya dengan hasil terbaik dengan melakukan pemakaian lidah buaya 1 kali 
dalam tiga hari. Pemakaian dalam waktu yang singkat ini dapat mempercepat proses pelembaban kulit tangan kering. Perawatan yang teratur meningkatkan kelembaban kulit tangan kering secara bertahap.

Merujuk dari hasil penelitian yang telah dilakukan maka peneliti menyimpulkan bahwa nutrisi yang baik untuk kulit tangan kering adalah Lidah Buaya, dengan pemakaian teratur dengan jarak pemakaian yang relative singkat (1 kali dalam 3 hari) dapat meningkatkan cepatnya pemulihan kondisi kulit kering. Kemudian untuk mendapatkan hasil terbaik untuk melembabkan kulit maka pemanfaatan lidah buaya untuk kulit tangan kering dapat dilakukan mengikuti prosedur yang telah dilakukan pada penelitian ini.

\section{SIMPULAN DAN SARAN}

Simpulan

Berlandaskan pada hasil analisis secara keseluruhan, maka diambil kesimpulan :

1. Tidak terdapat perubahan tingkat kelembaban kulit tangan kering pada kelompok kontrol (X1) yang dirawat tanpa pemanfaatan Lidah Buaya.

2. Terjadi perubahan pada tingkat kelembaban kulit tangan dengan kondisi normal mulai pada pertemuan ke 3, menjadi sangat lembab pada pertemuan ke 6 untuk kelompok perlakuan eksperimen 1 (X2) dengan pemanfaatan Lidah Buaya 1 kali 3 hari.

3. Terjadi perubahan tingkat kelembaban kulit tangankering pada kategori normal mulai dari pertemuan ke 5, hingga pertemuan ke 7 kondisi kulit tangan berkategori lembab untuk kelompok perlakuan eksperimen 1
(X3) dengan pemanfaatan Lidah Buaya 1 kali 7 hari

4. Terdapat perbedaan pengaruh perawatan tangan kering menggunakan Lidah Buaya melalui tiga perlakuan yang berbeda karena skor Signifikansi $0.005<0.050$, dan kelompok perlakuan dengan frekuensi 1 kali 3 hari memiliki hasil yang terbaik.

\section{Saran}

Setelah melakukan penelitian ini maka penulis dapat merekomendasikan beberapa saran, yakni kepada pihak-pihak:

1. Kepada Prodi Pendidikan Tata rias dan kecantikan Fakultas Pariwisata dan Perhotelan, hasil dari penelitian ini dapat menjadi masukan sebagai referensi bahan perkuliahan pada mata kuliah perawatan kulit bahwa Lidah Buaya dapat dimanfaatkan untuk mengatasi kondisi tangan kering dengan frekuensi pemakaian terbaik 1 x 3 hari.

2. Kepada masyarakat yang mengalami masalah kulit tangan kering, hasil penelitian ini dapat menjadi masukan yang bermanfaat untuk mengatasi permasalahan kulit tangan kering.

3. Para praktisi bidang kecantikan dapat memiliki referensi tambahan bahwa Lidah Buaya bermanfaat untuk mengatasi kulit tangan kering.

4. Bagi mahasiswa yang melakukan kajian penelitian sejenis penelitian ini dapat dijadikan referensi untuk kajian berdasarkan jurnal yang diterbitkan sesuai hasil penelitian ini. 


\section{DAFTAR PUSTAKA}

Darwati. 2013. Cantik Dengan Herbal. Jakarta: Tibbun Media.

Dwikarya, Maria, DSSK .2003. Merawat Kulit dan Wajah. Jakata: Kawan Pustaka.

Furnawanthi,I. 2002. Khasiat dan Manfaat Lidah Buaya. Jakarta: Agro Media Pustaka.

Gita, Fadhila. 2015. Pengaruh Penggunaan Masker Lidah Buaya Terhadap Perawatan Kulit Wajah Kering. Jurnal Pendidikan Tata Rias dan Kecantikan. Padang: Fakultas Teknik UNP.

Gloria, Novelita. 2016. Tips Menjaga Kelembaban Kulit. http://.imperial leather.co.id. Diakses 20 Oktober 2017.

Hakim, dkk. 2005. Anatomi dan Fisiologi Kulit Manusia. Jakarta: Penerbit Buku Kedokteran EGC.

Muliyawan, Dewi. 2013. A-Z Tentang Kosmetik. Jakarta: PT. Alex Media Komputindo.

Pipih, Tresna. 2010. Modul Merawat Kulit Wajah. Bandung: UPI.

Rosita \& Tim Redaksi Qonita. 2008. Sehat, Cantik, dan Penuh Vitalitas Berkat Lidah Buaya. Bandung: PT Maizan Pustaka
Rostamailis. 2005. Penggunaan Kosmetik Dasar Kecantikan dan Berbusana yang Sehat. Jakarta : PT. Rineka Cipta.

Santoso, Singgih. 2012. Panduan Lengkap SPSS Versi 20. Jakarta: PT Elex Media Komputindo.

Siregar F. 2011. Study Biologic Efek Getah Jatropha Curcas (Euphorbiaceae) Terhadap Jaringan Periapeks. Disertasi Fakultas Kedokteran. Jakarta: Universitas Indonesia.

Sulastomo, H. 2013. Manajemen Kesehatan. Jakarta: Gramedia Pustaka Utama.

Susiana. 2012. Nutrisi Kulit. Bandung: Balai Penerbit PGRI Bandung.

Tim Karya Tani, Mandiri. 2013. Pedoman Bertanam Lidah Buaya. Bandung: CV. Nuansa Aulia.

Widya, Novita. 2009. Buku Pintar Merawat Kecantikan Dirumah-Kumpulan Tips Praktis dan Murah Merawat Kecantikan dari Ujung Rambut Hingga Ujung Kaki. Jakarta: PT. Gramedia Pustaka. 